Paweł Plichta

\title{
Konferencja naukowa Postać Judasza w literaturze, teologii i sztuce (Białystok, 9 grudnia 2006)
}

9 grudnia 2006 odbyła się zorganizowana przez Instytut Socjologii Uniwersytetu w Białymstoku konferencja naukowa pt. Postać Judasza w literaturze, teologii i sztuce. W czasie obrad swoje referaty zaprezentowali kolejno: dr Jacek Sieradzan (Uniwersytet w Białymstoku) nt. Trzy oblicza Judasza: wspótpracownik Jezusa, zdrajca, bóstwo, mgr Krzysztof Matys (Uniwersytet w Białymstoku) nt. Judasz gnostyk, mgr Dorota Rojszczak (Uniwersytet Adama Mickiewicza w Poznaniu) nt. Pytanie o źródta: poczatki polskich zmagań z Judaszem, dr Beata Popczyk-Szczęsna (Uniwersytet Śląski) nt. Postać Judasza $w$ dramacie i teatrze polskim XX wieku (wybrane przykłady), mgr Paweł Plichta (Uniwersytet Jagielloński) nt. Na skrzyżowaniu egzegezy $i$ wyobrażeń literackich, czyli kreacja postaci Judy ben Symeon z Kerijoth w powieści Romana Brandstaettera „Jezus z Nazarethu”, Mirosław Miniszewski (Wyższa Szkoła Administracji Publicznej w Białymstoku) nt. Figura Judasza „Złego Żyda” jako element korzeni europejskiego antysemityzmu, dr Ewa Zgolińska (Akademia Podlaska) nt. Ikonografia Judasza - potępienie czy próby zrozumienia zdrady?, Piotr Gibaszewski (Uniwersytet Jagielloński) nt. Judasz i Tarot - alegoria przebaczenia, pokuty i przemiany, dr Paweł Ibek (Uniwersytet Jagielloński) nt. Judasz chrześcijański i gnostycki. Dwie wizje jednej postaci.

Konferencja miała charakter interdyscyplinarny, co wyraża się już w samych tytułach referatów. Wieloaspektowość tematu znajduje swoje uzasadnienie także w problemach, które ogniskują się wokół tej postaci: zdrada, odpowiedzialność, predestynacja, miłosierdzie, odkupienie, grzech, problem gnostyckich tradycji i odniesień, figura zachowań, kulturowe interpretacje, inspiracje i nawiązania.

Wśród wielu artefaktów (Judaszowy pocałunek, Judaszowe srebrniki, Judaszowe włosy, Judasz jako synonim zdrajcy, sprzedawczyka, obłudnika, człowieka podstępnego, topienie Judasza, Pocałunek Judasza Giotto di Bondone, Studium głowy Judasza Leonarda da Vinci, Pojmanie Jezusa Caravaggia, Judasz oddaje trzydzieści srebrników Rembrandta, postać z widowisk pasyjnych, wierszy, dramatów i powieści, filmowy Judas Charlesa Carnera) składających 
się na dzisiejsze wyobrażenie o Judaszu fundamentalnym odnośnikiem są teksty, które odegrały największą kulturotwórczą rolę, tj. cztery Ewangelie kanoniczne. Jakkolwiek poszczególne referaty bazowały w mniejszym lub większym stopniu na tekstach biblijnych, to można odnieść wrażenie, że właśnie tej perspektywy zabrakło w białostockim spotkaniu. Wielkim nieobecnym zmagań z Judaszem okazał się przedstawiciel środowiska egzegetów badających problem Judasza w pismach Nowego Testamentu.

Uwzględnienie różnych nurtów i płaszczyzn, w których Judasz wykorzystywany był jako swoisty punkt odniesienia, nie uprawnia do pominięcia najważniejszego źródła, jakim są teksty biblijne. Kwestia dwunastego apostoła powróciła współcześnie po dość silnym i medialnym impulsie, jakim było opublikowanie wyników prac i samego tekstu apokryficznej Ewangelii Judasza ${ }^{l}$.

To, w jaki sposób dziś postrzega się tę postać, i fakt, że wywołuje ona tyle także naukowych kontrowersji, pokazuje, że najsilniej oddziaływały przez wieki i nadal oddziałują obrazy, idee i refleksje tworzone w oparciu o biblijne przekazy wzmiankujące osobę Judasza.

Kraków

PAWEE PLICHTA

${ }^{1}$ „Gazeta Wyborcza” z 7 i 18 kwietnia 2006 oraz „National Geographic” 5 (2006). 